\title{
The First Republican Election Victory in Iowa
}

\author{
By Morton M. Rosenberg \\ Associate Professor of Social Science \\ Ball State Teachers College
}

Noteworthy about the Iowa political scene during the middle years of the 1850 's was the existence of several groups of political dissidents who were unaffiliated with any of the organized political parties in the state. Free Soilers, antiNebraskaites, temperance advocates, abolitionists, disenchanted Democrats, disgruntled Whigs-all provided fertile ground for political ferment.

Regular Democrats and Old-line Whigs, as well as the antiforeign, anti-Catholic Know-Nothing Party sought to enlist these splinter elements behind their respective platforms. Since the Whig organization, though ostensibly triumphant over the Democrats in the vitally important gubernatorial election of 1854, had largely disintegrated, the Iowa Democracy, as the Democrats often called themselves, could look to future political campaigns with renewed optimism. The union of the diverse splinter groups into an effective political organization could, however, destroy the power of the Democrats in Iowa.

The election of 1854 had provided the leader who possessed the necessary ability to fuse the various opposition groups, together with the main body of the Old-line Whigs, into a compact and efficient political machine. Such a person was Governor James W. Grimes who had won a bitter, uphill battle for the gubernatorial office against a solidly entrenched but sharply divided Democratic opposition.

Grass-roots support for a new political party manifested itself as early as the summer of 1854 when a Republican organization was formed in Fayette county with a strong antislavery base as its raison d'etre. Later, on November 29 , the Burlington Daily Telegraph, a self-proclaimed political neutral, suggested that a Republican party should be established on a state-wide basis. In April of the following year, James Grimes indicated to Salmon P. Chase of Ohio that "it is time 
to thoroughly organize the Republican party," which, he believed, would draw support from the state's sizeable foreign-born population as well as from the outspoken nativists.

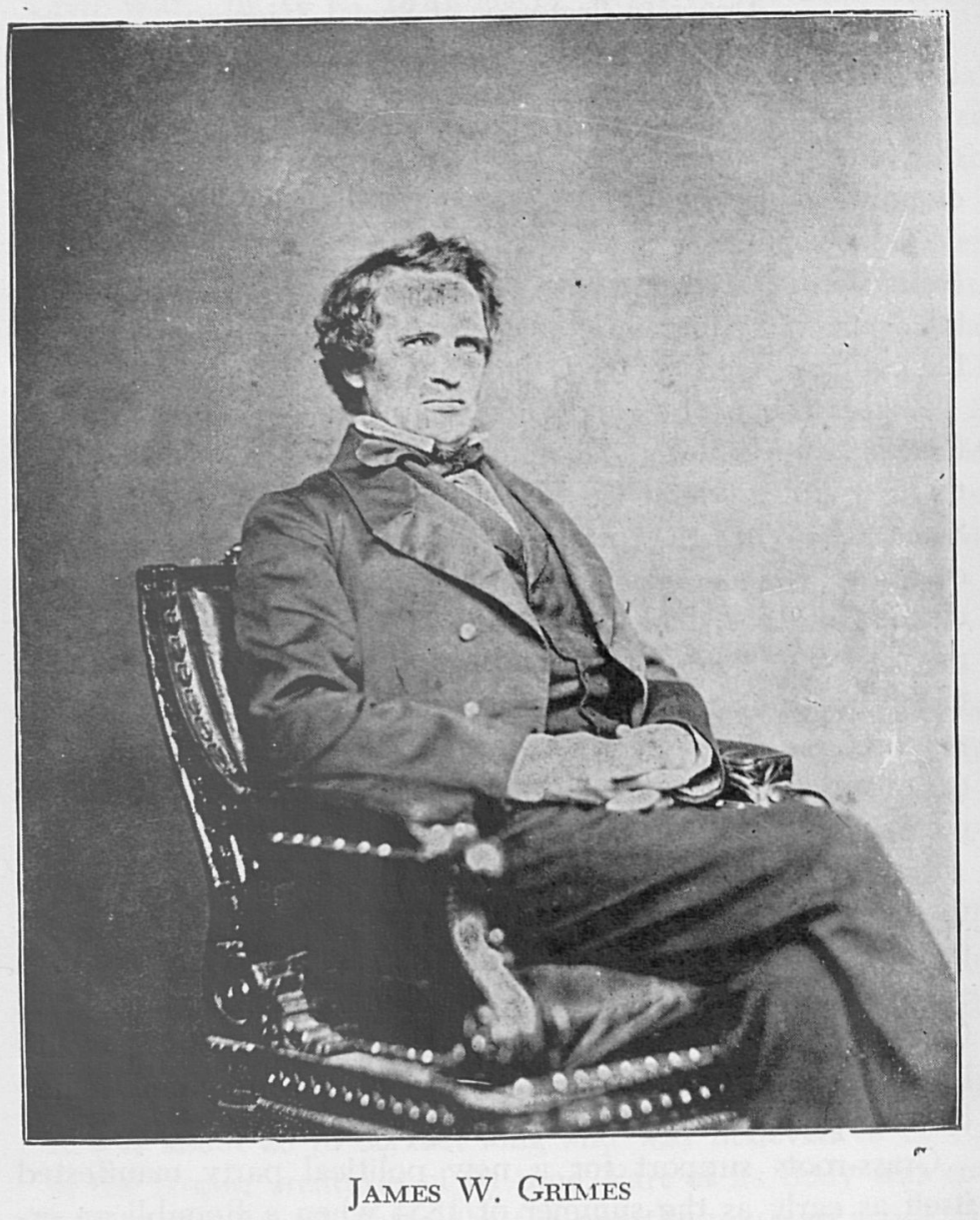

Word of an impending Republican state convention began to circulate in December, 1855, even before the publication of the official announcernent. In order to persuade the KnowNothings to join in a common cause with them, some Republicans-to-be suggested that their convention should coincide with the Know-Nothing meeting. All that would be necessary to unite the two groups would be an agreement on the basic 
issues, ignoring minor questions and differences. Indeed, this is what occurred, even though the two groups met separately. The Dubuque Times boasted that thousands of Know-Nothings had joined the Republican party, while at the same time "desiring .... that the purity of the elective franchise should be preserved, and that Jesuitism and poltical Romanism should not combine to endanger the peace and safety of our institutions." Grimes, himself, was convinced that the KnowNothings, whose principles he personally abhorred, were serving the useful function of destroying the old party alignments.

On January 3, 1856, the official call went out for a convention to gather in Iowa City on February 22 for the purpose of organizing a Republican party. Believing that many persons had joined the Know-Nothing party merely on a temporary basis for want of any other desirable organization, Republican leaders were confident that a sizeable number from the nativist group would join the new party. Although it was not specifically known at the time, it appeared quite probable that Governor Grimes had penned the call and would be the leading figure at the Iowa City convention.

When the convention assembled on the appointed date, it not only proceeded with the contemplated organization, but it also nominated a full slate of candidates for the various state offices to be filled later in the year, and selected delegates to attend the party's national convention. In addition, it drew up a platform and published an address to the people of Iowa which, more or less, restated the party's principles as expressed in its platform.

Since representatives from virtually all of the splinter groups attended the meeting, it was essential that nothing be adopted which might give offense, lest the entire effort to effect a unified party should end in failure. Thus, the platform was essentially a statement of the party's anti-slavery sentiments. The Republican Party, according to one plank, had a "mission... to maintain the Liberties of the People, the Sovereignty of the States, and the Perpetuity of the Union." Slavery was a local institution "beyond our reach and above our authority," but with regard to the territories "we will oppose its spread." Other planks condemned the South and denounced the national Democratic administration and declared 
that the federal government was one of limited powers. The last clause probably was inserted to satisfy both the Old-line Whigs and the former Democrats who were present.

On the more controversial local issues which could have divided the convention, such as temperance and nativism, the Republican platform remained discreetly silent. Since Prohibition had already been approved by Iowa voters during the previous year, a strong stand on this question would have provoked needless strife with those who had opposed the measure. Silence might disappoint temperance men, but would not offend them. Anti-temperance forces undoubtedly harbored some resentment owing to this omission.

But failure to condemn the Know-Nothings, a deliberate attempt to avoid alienating former members of the nativist party, aroused a good deal of anger and chagrin among the foreign groups in the state, particularly among the Germans who were especially sensitive to any anti-foreign sentiment. Moreover, since they had already been angrily stirred by the successful enactment of Prohibition, the presence of temperance men at the Republican convention could not have been very pleasing to them. Governor Grimes, himself, commented that the Germans resented the failure of the convention to state categorically that it abided by the existing federal naturalization laws. The reason for this, Grimes explained, stemmed from opposition from Know-Nothings as well as from others who preferred merely an anti-slavery platform and nothing more.

The editors of three of the leading German language newspapers in Iowa, the Burlington Die Freie Presse, the Davenport Der Demokrat, and the Dubuque Die Staats Zeitung, declared that they were not satisfied with the position taken by the Republican party on the question of nativism and naturalization laws. A meeting of Germans in Dubuque adopted a number of resolutions echoing this disappointment. It remained to be seen how the Germans would vote in the elections of 1856 .

In the meantime, county Republican organizations continued to spring up, both before and after the state convention of the new party. In most cases these merely replaced the old Whig groups, but on a more broadened base to include 
the splinter elements. The county platforms generally repeated the pronouncements of the state organization on the main issue of slavery.

The Democratic press, of course, greeted the formation of the new party with scorn and derision. The Iowa State Gazette declared that the aims of the new party were "to distract the country and imperil the Union," for it could prevent the admission of any new state into the Union which might adopt a slavery constitution. The Reporter of Iowa City charged that "Republicanism is ... [synonymous with] . . Abolitionism." The new organization had merely changed names, but had not abandoned its old characteristics. The Pella Gazette suggested that the new party should be called "Black" because sympathy with the black race was it major tenet. Most anti-Republican newspapers did, in fact, call their rivals "Black Republicans" as a matter of course. Nor did Republicans shirk from employing a few choice epithets of their own when referring to the Democracy.

In the elections of 1856, the Democrats of Iowa would face a series of contests against a party which was substantially united and embraced the various splinter groups of the state. The Democracy, however, continued to reel from the schism over the Nebraska issue, railroads, temperance, nativism, and other local and national questions. The outcome of the 1855 campaign would attest just how well Grimes and his allies had done their work of political reconstruction.

In order to repossess their quarreling elements and mold them into a smoothly functioning, harmonious unit the leaders of the Iowa Democracy needed to exhibit a spirit of conciliation. Rankled feelings and ruffed nerves called for balm rather than whip. Yet, the men who ran the party, principally Senator George W. Jones and his supporters, refused to compromise with their disaffected brethren, and insisted, instead, that only loyal supporters of the national Administration be permitted to attend the party's state convention on January 8 , 1856 to select delegates to the national convention and to nominate candidates for the local ticket. Loyalty to the national Administration and its policies would be the essential test of party orthodoxy.

The Democratic state platform clearly reflected the pre- 
dominance of Administration supporters in the convention. After paying the usual lip service to the Constitution and to equal justice for all states regardless of section, the platform strongly lauded the Kansas-Nebraska Act and excoriated all those, Democrats included, who had raised their voices in opposition. President Pierce and his official family received a ringing endorsement, while the state administration of James Grimes and his circle merited strong rebuke. Another plank condemned the Know-Nothings by name and read out of the party any Democrat who belonged to the secret nativist order. On the other issues vital to the interests of Iowans, such as homesteads, banking, internal improvements, and railroad grants, the party solons remained silent.

The best thing that can be said for the Democratic platform is that it was inept. At least one interested observer forecast a probable defeat for the Iowa Democracy because of its uncompromising stand on the Nebraska question as a test of party fidelity.

The state convention weighted its delegates to the national Democratic convention at Cincinnati with administration men and likewise chose 'trusted' men to be candidates for the local offices. If the renegade Democrats had expected to be conciliated at Iowa City, they must have been sorely disappointed.

At Cincinnati the Democrats adopted a platform designed to preserve the unity of the national organization. In various introductory planks, the Democrats reaffirmed their opposition to a national bank and internal improvements, reiterated their belief in the principle of states' rights, and called for a strict interpretation of the Constitution. The crucial portions of the platform, however, concerned slavery. Not only did the Democrats pledge to resist the renewal of the slavery controversy, but they went on record as endorsing the principle of "non-interference by Congress with Slavery in State and Territory, or in the District of Columbia." Closing portions of the platform condemned the Republcan and Know-Nothing parties and heartily lauded the Pierce Administration.

Although some individuals like Charles Mason viewed the action of the Democrats with a critical eye and were especially hostile to the platform, Administration partisans, blinding 
themselves to the discontent which ripped the party, expressed optimistic hope of victory in the coming political struggle. Thus, P. M. Casady could assure Senator Jones, leader of the Administration group, that the party in the Polk County area "will certainly succeed." Another Democrat confidently believed his party would carry the state.

Most portents, however, forecast a stunning disaster for the Democracy unless the leadership awakened to remedy its ailments. From the various corners of the state, messages warned and editorials declared that the Germans were beginning to desert the Democrats and were joining the Republicans. The latter, it should be remembered, had adopted a strict antislavery plank in response to the Democratic Nebraska endorsement. While the Germans received the platform of the new party lukewarmly and with reservations, they could, and did, accept its pronouncements on slavery. In Keokuk, however, German dissatisfaction stemmed not so much from slavery as from a more personal issue intimately connected with the pocketbook-wages for labor. Apparently they believed they were victims of wage discrimination.

Dissension within the ranks, unified opposition under a new party label, and the possibility of having alienated some of its foreign-born adherents were not the only difficulties confronting the Iowa Democracy in 1856. The American Party, commonly labeled Know-Nothings, had blossomed into a potentially strong group with county and state organizations and with a press of its own. The national convention of the American Party met in Philadelphia on February 22 and chose Millard Fillmore for President and Andrew J. Donelson for Vice-President. The Know-Nothing platform reasserted its basic nativist tenets and condemned the national Democratic Administration for passing the Kansas-Nebraska measure, thereby reopening the slavery controversy.

Know-Nothing supporters in Iowa greeted the action of their national convention somewhat unenthusiastically. The backers of Fillmore and Donelson sought to drum up interest in the state convention of the nativist order, scheduled to meet in Iowa City on March 5. When the date for the meeting arrived, attendance was disappointing. The 45 delegates who did attend, endorsed the national nominations. They chose a 
slate of presidential electors and adopted a Prohibition resolution in addition to the usual nativist planks.

Another sparsely attended Know-Nothing meeting convened at Chariton, Lucas county, in May. Delegates endorsed the Fillmore-Donelson ticket and the Philadelphia resolutions, and nominated John J. Selman for Congress from the First District. A meeting of members of the nativist order at Oskaloosa, also in May, refused to go along with the Philadelphia platform or the party's ticket, and condemned both. Thus, the Know-Nothings were themselves weakened by factionalism, caused partly, no doubt, by the formation of the Republican party which former Know-Nothing adherents could join without necessarily compromising their nativist attachments or antislavery principles.

Notwithstanding the evidence of Know-Nothing weakness in Iowa, a few party newspapers strove valiantly to popularize their candidates. Fillmore received praise as the one man not pledged to either of the warring sections of the country. His two opponents, John C. Fremont, Republican, and James Buchanan, Democrat, were sectional candidates; the former was too friendly to the North, while the latter was a captive of the South. In addition, Fremont was a Catholic! Thusly, did Know-Nothing editorials rant down to the day of the election.

The Republicans were determined to take both Congressional races from the Democrats in addition to the other offices at stake in the coming elections. In the Second District, embracing the Northern portion of lowa, they chose Timothy Davis to run against the Democratic nominee, Shepherd Leffler. The latter, a Pennsylvanian, an alumnus of Washington College, and a resident of Burlington since 1835, had served in Congress from 1846 to 1850 . In the Congressional election of 1848 , the defeated rival was this same Timothy Davis. Like Leffler, Davis, a New Jersey native, could boast of long residence in the state, having gone to Dubuque in 1837 by way of Kentucky and Missouri. Democrats had not controlled the Second District since 1852, and now the Republicans could claim it as their own private bailiwick.

In the First District, or Southern part of Iowa, the Democrats renominated the incumbent Augustus Hall, a staunch 
FIRST REPUBLICAN ELECTION VICTORY IN IOWA

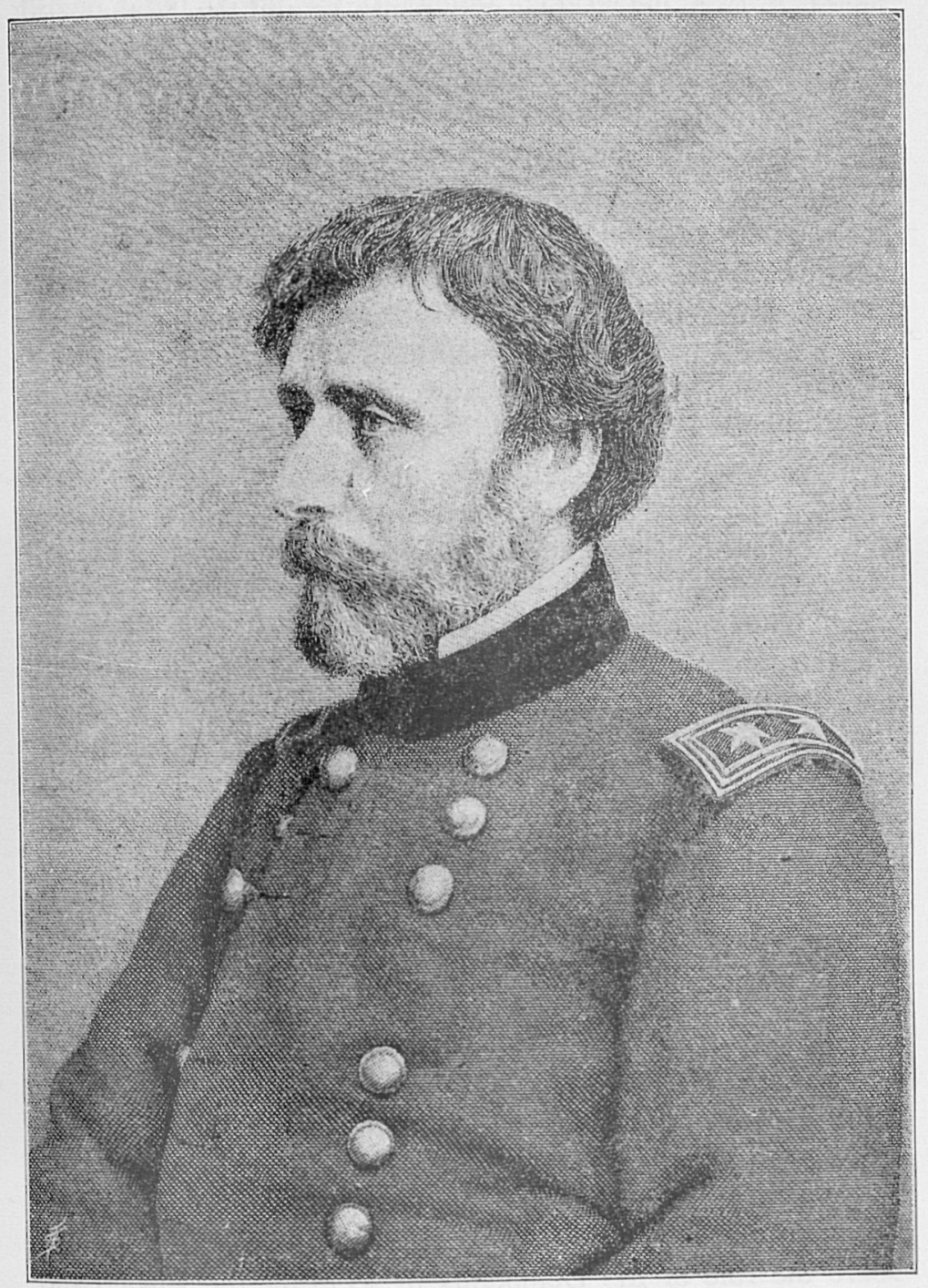

\section{John C. Fremont}

Administration and Nebraska supporter. This strategy seemed wise for Hall had demonstrated his vote-getting ability two years earlier, when he won with a pro-Nebraska platform. The Republicans, however, trotted out a sure-fire issue to 
enable them to defeat their opponents. In addition to the usual condemnations of slavery, the passage of the Kansas-Nebraska Act and the repeal of the Missouri Compromise, they adopted a plank concerning railroads in which they condemned Hall for "negligence and inefficiency" owing to his failure to secure federal grants of land to aid in the construction of other railroads in the District apart from the grant which Congress had approved for Iowa in 1856. Moreover, to run against Hall. the Republicans selected Samuel R. Curtis, a West Pointer and former railroad surveyor and engineer. The railroad issue had earlier unseated one Democratic Congressman; perhaps it could defeat another.

In many ways the Republican party of Iowa was born under a lucky star. The Iowa Land Grant, for example, had come at an opportune moment politically. In mid-May of 1856 Congress passed an act which gave Iowa approximately four and a half million acres of land from the vast public domain for the purpose of assisting in the construtcion of railroad lines across the state. The demand for railroads was strong among Iowans. Western Iowa, during the middle years of the 1850's, maintained communication with the Eastern portion of the state by means of the stage coach, which scarcely could equal the railroad coach in comfort and speed. Produce usually made its way down navigable streams in order to reach the larger towns and cities for shipment to the South or East. Rapids just above Keokuk, however, impeded traffic on the Mississippi River. Railroads could by-pass such river obstructions. The chief means to insure the construction of railroads in a state where capital was limited and traffic scanty was to secure a Congressional gift of land. Indeed, Iowa's delegation to Congress, both Democratic and Whig, had labored diligently for years to obtain such a grant of land. For political reasons, however, the Republicans of Iowa sought successfully to obscure the role of the Democrats in securing the Iowa Land Grant.

Fortuitous also for the Republicans was the creation of a new political issue which dropped into their laps to aid them during the 1856 campaign. Within the space of a single week, national passions became heated again as Preston Brooks played the role of avenger against Charles Sumner, and John 
Brown acted as the self-appointed agent of the Lord at Ossawattamie following the Southern attack upon the Free Soil town of Lawrence, Kansas. Kansas and the troubles there became the chief issue of the election campaign in the Hawkeye state. Indeed, Kansas became a veritable crusade, charged with enough moral tones to arouse the entire nation, let alone a mere section or a single state.

In Congress, Iowa's delegation carried on a running battle against one another over the Kansas question. While Democrat Augustus Hall, in the House, defended popular sovereignity and denied that the national government could interfere in any way with the proceedings in Kansas, Whig-turnedRepublican James Harlan, in the Senate, insisted that the federal government possessed the power to regulate slavery in the the territories and, hence, in Kansas. He demanded the admission of Kansas into the Union under its free Topeka Constitution. Democratic Senator, George W. Jones, replied to his Republican colleague three weeks later, holding steadfastly to the Administration line on the Kansas problem, denying the right of the federal government to interfere in Kansas and backing popular sovereignity. "The people of Kansas," Senator Jones declared, had the right to decide "for themselves this question of admitting slavery within their borders, and to be admitted into the Union with or without it, as they may elect."

In Iowa, the Democrats charged their foes with deliberately stirring up emotions over the Kansas situation in order to enhance the chances of success for their ticket. Iowa, wrote United States Marshal Laurel Summers, "is literally overrun with 'interlopers' haranguing the people in favor of 'free Kansas' as they say. Fanaticsm is the order of the day and among a certain class of people all love for the Union and Constitution seems to have fled." Even a number of Republicans conceded that much of the excitement over Kansas was "made for electioneering purposes."

Perhaps one of the reasons why the Republicans, and indeed many other Iowans, felt so keenly about Kansas was that they were not discussing an abstract issue, but had long been engaged in playing positive roles in the bitter conflict which raged in that territory between free-state and slave- 
state men. Many Iowans were active in the operation of the Underground Railway which spirited runaway slaves through the North and into Canada. One of the routes extended across the state from Tabor in the southwest corner, through Des Moines and Iowa City, on up to Clinton, and across the Missississippi River into Illinois. Fugitive slaves were also taken through Appanoose county, one of the Democratic party's strongholds along the southern tier of counties. Many of the operators of the underground transit system transported a different cargo back along these same routes, this time carrying guns and munitions to be used against the pro-slavery forces in Kansas. The little town of Tabor became the headquarters of the northern Kansas forces. Free-state men made little or no effort to conceal their trips through Iowa, backed as they were by a Kansas Committee operating in the Hawkeye state. Iowa City became the eastern focal point in the state for the free-state adherents.

Responsible leaders of the Republican party were among those who actively and energetically supported and encouraged the movements of men and munitions to and from troubled Kansas. William Penn Clarke, a former fiery Free Soil Party leader, was chairman of the Kansas Committee in Iowa. He assisted John Brown on more than one occasion. A member of the Republican State Central Committee, Henry O'Connor, spent considerable time in Kansas in behalf of the free-staters. Governor James W. Grimes, as chief executive of Iowa, wrote to President Pierce demanding federal protection for Iowans who migrated to Kansas. Unless the federal government acted promptly to protect the lives and property of Iowans in Kansas, Grimes threatened to take state action to achieve this end. Later in the year, he asked the Iowa General Assembly to support his bold statements. Grimes, moreover, developed an astonishing lapse of memory in order to aid the anti-slavery cause in Kansas. He carelessly left the key to the Iowa arsenal on his desk one day, where it was found by the 'proper' Kansas man who then appropriated some 1500 muskets from the stock available for use in Kansas. Josiah B. Grinnell was another prominent Republican who more than once entertained John Brown in his home and supplied him with whatever materials he could collect. 
Still, despite the Kansas crisis, some Republicans were pessimistic about their party's ability to carry Iowa. William Penn Clarke wrote to Senator James Harlan asking him to obtain outside speakers to stump the state. Harlan replied that national Republican leaders considered Iowa safe for the party and that local speechmaking efforts would have to turn the trick. The Senator admitted, nevertheless, that he was not as confident about Iowa as the national party spokesmen. Republican campaign speakers, such as Charles C. Nourse, who attempted to stump for the party in areas of Democratic preponderance, faced hostile crowds arwed with rotten eggs. Here, he and his supporters were called "damn black republicans."

Democratic campaign tactics, meantime, were weak and ineffectual. The Republicans, the Democracy charged, were purely a sectional group, while the Democratic party was a national organization, and had the best interests of the Union at heart. At the same time the Democrats assailed the antiforeign, anti-Catholic bias of the Know-Nothings, and promised to strive "for the free, unrestrained, unlimited, and unqualified right of Catholics as well as others to worship God according to the suggestions and dictates of their consciences and without subjecting them to any political disabilities whatever therefor." Moreover, continued a staunch Democratic journal, the party "will insist also upon the unrestrained right of slave-holders, as of others, to migrate with their goods and chattels to the Territories of the United States. So far as the Democracy was concerned, it did not intend to bother itself with any moral pronouncements on the subject of slavery pro or con. Hence, the Democracy was able to do little or nothing to counter the emotional appeal and moral attractiveness of the Republican position with regard to the Kansas issue. To be sure, Kansas was bleeding a bit. The Republicans, however, transformed the rivulets of blood into a veritable flood of gore for public consumption throughout Iowa.

On August 4, 1856, the voters of Iowa went to the polls to cast their ballots to fill the Congressional seats as well as the lesser state offices. The results of the election stunned the Iowa Democracy. In their very first campaign in the Hawkeye state as an organized political party, the Republicans swept 
the election with ridiculous ease. They captured all the state offices by margins of 7,500 votes or better and secured control of the General Assembly by a two-to-one majority in each branch of the Legislature.

In the Congressional races, Democrats relinquished their control of the First District for the first time in the state's brief history, while the party defeat in the Second District was even more decisive. Here, Timothy Davis whipped Shepherd Leffler by a vote of 21,885 to 15,870 . The former received 57.89 per cent of the total vote, the largest percentage won by any victorious candidate during the 1850 's. Leffier carried only six of the 43 counties in his District including the Democracy's Dubuque stronghold. Four of the Dernocratic counties, Boone, Greene, Story, and Woodbury, are located in the western portion of the District, attesting to the overwhelming Republican superiority in Eastern Iowa.

In the Frist District, the incumbent Augustus Hall succumbed to his Republican rival, Samuel R. Curtis, in a close contest complicated somewhat by the presence of a third party candidate, John Selman of the Know-Nothings. Hall received 17,110 votes in contrast to Curtis' 18,065 votes. In percentage figures, Curtis attracted 50.17 per cent of the vote, while Hall obtained 47.52 per cent, and Selman lured 2.29 per cent with his 826 votes. Hall's figures represent a decline of 2.75 percentage points over the totals he had received in 1854 . John Selman obtained most of his support from the Southern counties, Appanoose, Davis, Henry, Lee, and Lucas, all of which, with the exception of Henry, went Democratic by comfortable margins.

Whether the German vote was a significant factor in the Republican sweep of the Congressional races is open to question. In the First District, 4,194 persons, not all of whom were of German origin, were naturalized and entitled to cast ballots. Of this number, 3,018 resided in counties carried by the Democrats or in counties where Hall's percentage change from his 1854 figures was negligible. Another 422 citizens of foreign birth lived in Henry, Mahaska, Jasper, and Warren counties, where Curtis compiled majorities totalling more than 2000 votes. An additional 442 naturalized voters resided in ten counties which switched to the Republican column. In only 
two of these counties, Keokuk and Monroe, where Curtis' margin of victory was slender, the German vote may have been a significant factor in his triumph. His pluralities in the other eight counties combined were more than triple the number of naturalized persons living there. The remainder of the naturalized voters made their homes in counties which gave Curtis thumping majorities, far exceeding the number of foreignborn voters. Hence, one can only conclude that in the First Congressional District as a whole, the German vote was not a decisive factor in the defeat of the Democrats. Although the German vote may have been significant in certain counties such as Keokuk and Monroe, even this possibility cannot be demonstrated with absolute certainty.

The same conclusion must apply also to the Second District which contained 10,295 naturalized voters. The German vote may have been responsible, in part, for the defection of four counties, Bremer, Des Moines, Jackson, and Johnson, to the Republican column. Davis' margin of victory in these counties with 1,708 naturalized voters totalled 397 votes. Elsewhere in the District, the Democrats carried six counties with 2,268 foreign-born voters, and scored gains in eight Republican counties having 3,028 naturalized voters. Twelve counties cast ballots for the first time in a Congressional election. These went overwhelmingly to Davis, but only 353 citizens of foreign birth resided in these newer counties. In twelve other counties, where the Democracy suffered percentage losses, there lived 2,919 naturalized persons, but Davis' victory margin exceeded this number by more than 500. Thus, except for the four counties enumerated above, it is doubtful whether the German vote in the Second District did little more than to add a few hundred votes to Davis' already imposing margin of victory.

In November, the voters of Iowa again journeyed to the polls, this time to register their preference for President. Again the Democrats were soundly trounced. Of Iowa's 101,300 eligible voters, more than 92,400 exercised their franchise privilege, giving Fremont 45,174 votes, Buchanan 37,568 votes, and Fillmore 9,669 votes. Fremont won 48.88 per cent of the total vote, Buchanan attracted a mere 40.65 per cent, and Fillmore received a surprising 10.46 per cent.

Democratic strength, as usual, was concentrated along the 
Southern tier of counties, in Dubuque county, and in a cluster of five counties in central Iowa. Pottawattamie and Woodbury counties, in the western part of the state, also returned heavy Democratic majorities.

The Repulicans dominated Northern and Eastern Iowa for the most part, and scored victories in two groups of counties in the southwestern sector of the state. The northern and eastern portions of the state had long ceased to furnish the Democracy with any reason for political joy.

Fillmore attracted his largest following from the southern counties, but his appeal elsewhere was also somewhat considerable. Fillmore's popularity ran deeper than his association with the American Party. His close connection to the Compromise of 1850 undoubtedly contributed not a little to his appeal to Iowans.

Despite the universality of the Democratic defeat in the state, party leaders nevertheless found something to celebrate in the triumph of the Buchanan ticket in the nation. A gala victory celebration took place in Dubuque to the accompaniment of speeches and bonfires, but the Democrats could not eradicate the fact that the Republicans had carried the state overwhelmingly. Still, the Express and Herald of Dubuque declare that "the most dangerous political organization this country has ever seen" had been beaten nationally. The Republicans, the Express insisted, sought only spoils and power, not principles and Union.

Thus, the infant Republican Party of Iowa, expertly led by James Grimes, James Harlan, William Penn Clarke, and a host of other capable political figures, brilliantly parlayed a series of fortunate circumstances into a smashing victory in its first encounter with the Democratic opposition. The splintered, dissident elements had indeed been effectively molded into a powerful force which, acting together with the regular Whigs, would enable the new party to continue to wield the reins of political power in the state during the waning years of the final Ante Bellum decade.

Moreover, the new party, needing a broad base upon which to appeal to Iowa voters in addition to the slavery question, tied its future in large measure to the railroad, as the victory 
of Samuel R. Curtis partly attests. Republicans continued to champion railroad construction throughout the state, and reiterated Western desires for a line to the Pacific. Some of the leading figures in the Republican organization were, or soon would be, intimately associated with one railroad line or another. In addition to Curtis, such Republican leaders as James

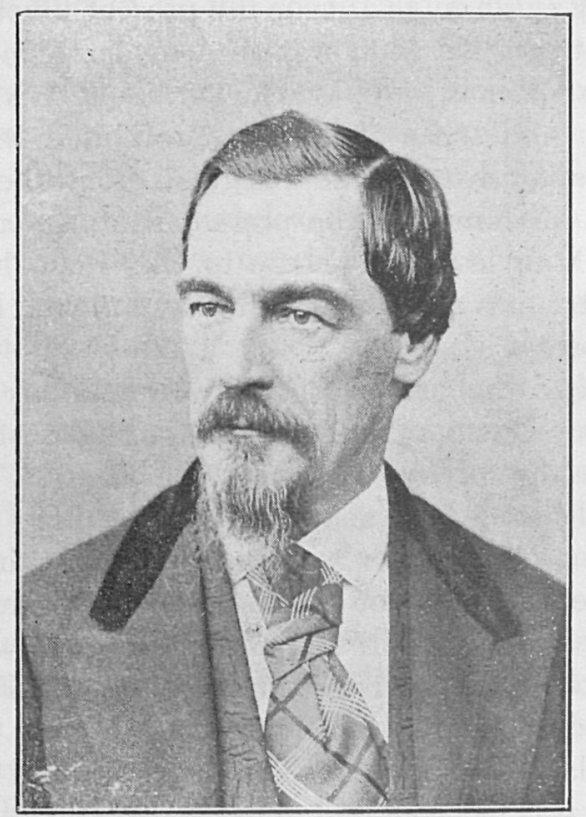

Wimliam Penn GlakKe

Grimes, James Harlan, Grenville Dodge, William Penn Clarke, H. M. Hoxie, and John Kasson were closely connected with railroading in one capacity or another. Many lesser figures in the party also had railroad interests. While the Republican Party grew out of the slavery controversy, it employed the railroad question, together with several other key issues, to maintain itself in power in Iowa. The results of the elections of 1856 certainly testify to the efficacy of such a policy. 
Copyright of Annals of Iowa is the property of State of Iowa, by \& through the State Historical Society of Iowa and its content may not be copied or emailed to multiple sites or posted to a listserv without the copyright holder's express written permission. However, users may print, download, or email articles for individual use. 